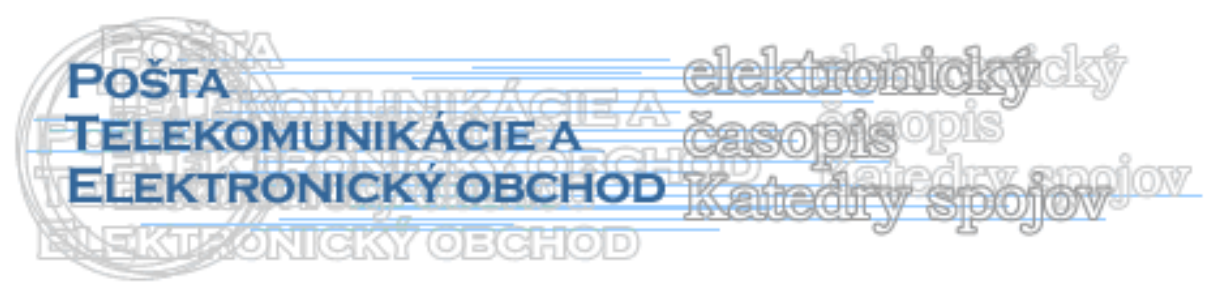

\title{
ŠIROKOPÁSMOVÝ PRÍSTUP V SLOVENSKEJ REPUBLIKE - POROVNANIE S OSTATNÝMI ŠTÁTMI V4
}

\author{
Juraj Fabuš*
}

Úvod

Séria článkov vzniká za účelom vysvetlenia a objasnenia pojmu širokopásmový prístup, hlavnou témou tohto článku je porovnanie stavu širokopásmového prístupu v Slovenskej republike s ostatnými štátmi V4.

Zverejnenie práce je $\mathrm{z}$ dôvodu obšírnosti problematiky rozdelené do viacerých článkov, ktoré budú postupne publikované $\mathrm{v}$ tomto elektronickom časopise. V predchádzajúcich častiach boli vysvetlené základné pojmy z predmetnej oblasti, charakterizované jednotlivé služby, ako aj význam a výhody uplatnenia širokopásmového prístupu. Bol porovnaný stav v SR a EU. V d'alšej časti bude nasledovat' návrh opatrení, ktoré napomôžu k rozšíreniu využívania širokopásmového prístupu pre všetkých obyvatel'ov SR.

Ciel’om je zvýšit' povedomie o širokopásmovom prístupe, zvýšit' záujem o jeho využívanie, čo bude mat' konečný vplyv aj na postavenie Slovenska v rámci EÚ, kde sme medzi členskými krajinami na poslednom mieste vo využívaní širokopásmového prístupu. Články sú určené všetkým, ktorí širokopásmové služby už využívajú, ale aj pre tých, ktorí sa s nimi ešte len zoznamujú.

\section{Stav širokopásmového prístupu}

Slovensko v súčasnosti využíva najrozšírenejšie technológie širokopásmového prístupu. Najviac využívanou je DSL. Obrázok č. 1 zobrazuje stav pevných širokopásmových prístupových technológií v SR (stav k 1.1. 2008).

\footnotetext{
* Ing. Juraj Fabuš, PhD., Žilinská univerzita v Žiline, Fakulta prevádzky a ekonomiky dopravy a spojov, Katedra Spojov, Univerzitná 1, 01026 Žilina, Slovenská republika, tel.: +421 908171 890, E-mail: juraj.fabus@fpedas.uniza.sk
} 


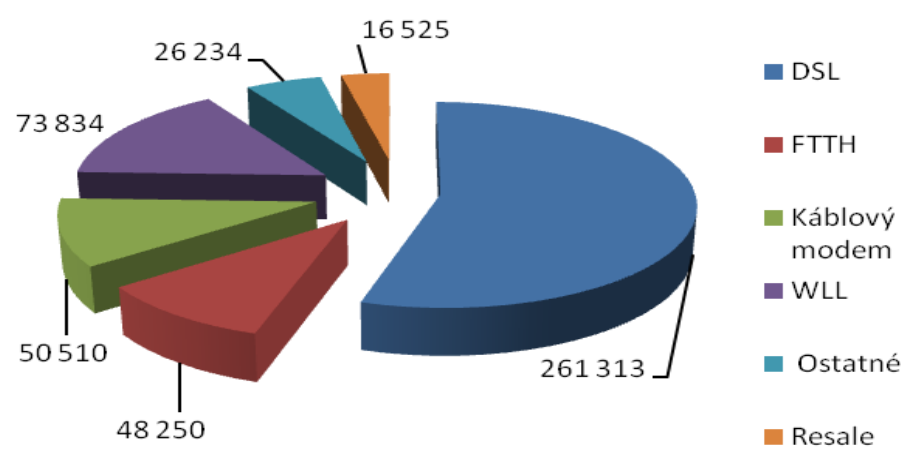

Obrázok 1. Analýza súčasného stavu pevných širokopásmových prístupových technológií v SR

Dostupné na: <http://ec.europa.eu/information_society/doc/factsheets/13thimplementation/9-23-sk.pdf>

V nasledujúcej časti je popísaný stav širokopásmového prístupu v krajinách V4, teda v Pol'sku, Českej republike a Mad'arsku.

\section{Pol'sko}

Pol'ský trh telekomunikácií je aktuálne otvorený pre konkurenciu na všetkých úrovniach. Napriek dynamickému rastu počtu širokopásmových pripojení v Európe, v Pol'sku pretrváva nízka penetrácia širokopásmového prístupu. V roku 2006 nastalo značné zvýšenie počtu internetových uživatel'ov, ale v porovnaní s ostatnými krajinami EÚ stále zaostáva, podobne ako Slovensko.

Pol'ský regulátor - Úrad elektronických komunikácii tvrdí, že tento stav je spôsobený najmä vysokými cenami za širokopásmový prístup. Polska Telefonia Cyfrowa (PTC) - hlavný mobilný operátor v Pol'sku začala poskytovat' HSDPA v roku 2006. PTC pokrýva až 20\% obyvatel'stva. Taktiež spoločnost' Polkomtel spustil v roku $20063 \mathrm{G}$ siet'. Obrázok č. 2. zobrazuje stav pevných širokopásmových prístupových technológií v Pol’sku (stav k 1.1. 2008).
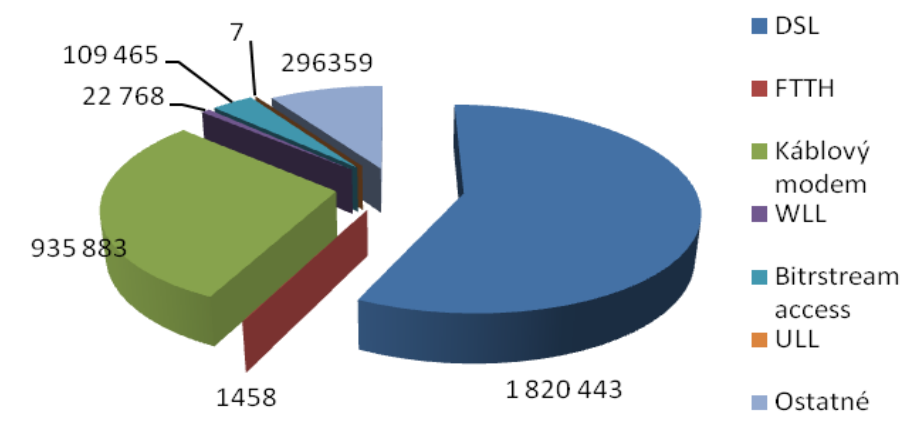

Obrázok 2. Analýza súčasného stavu pevných širokopásmových prístupových technológií v Pol’sku (

Dostupné na: <http://ec. europa .eu/information_society/doc/factsheets/13thimplementation/9-20-pl.pdf> 


\section{Česká republika}

Telekomunikačný trh bol v Českej republike liberalizovaný v roku 2001. V roku 2004, český Telecomminications Office (CTO) uložil záväzok všetkým držitel'om spojit' vzájomne siete s alternatívnymi operátormi za účelom poskytovania alternatívnych ADSL služieb.

T Mobile spustil komerčné $3 \mathrm{G}$ služby v roku 2005, neskôr spustil aj služby $4 \mathrm{G}$ siete, čo prinieslo vysokorýchlostný, mobilný Internet a širokopásmový prístup pre viac ako $60 \%$ českých domácností. V máji 2007, novo prijatý člen českého mobilného trhu, MobilKom spustil U:fon siet', s ktorou pokryl až $90 \%$ obyvatel'stva. Obrázok č. 3. zobrazuje stav pevných širokopásmových prístupových technológií v ČR (stav k 1.1. 2008).

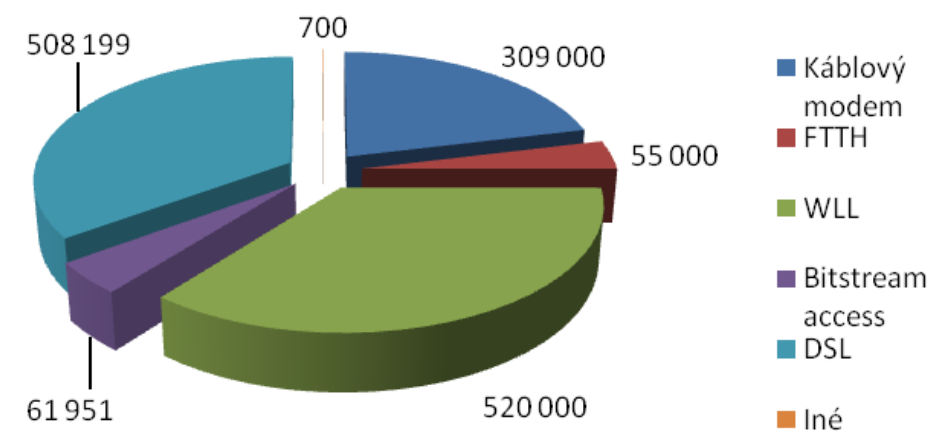

Obrázok 16. Analýza súčasného stavu pevných širokopásmových prístupových technológií v Českej republike

Dostupné na: <http://ec.europa.eu/information_society/doc/factsheets/13thimplementation/9-5-cz.pdf>

\section{Mad'arsko}

Od roku 2007 sa penetrácia širokopásmového prístupu domácností rástla. Od novembra 2007 bolo v Mad'arsku evidovaných 2,5 milióna pevných pripojení, pričom penetrácia domácností bola na úrovni $62,7 \%$.

Aj v Mad'arsku T-Mobile predstavil HSDPA službu na podporu širokopásmového rozvinutia. Širokopásmový mobilný prístup ponúka operátor s názvom Pannon. Obrázok č. 3 zobrazuje, vakom pomere sú využívané jednotlivé pevné širokopásmové prístupové technológie v Mad'arsku (stav k 1.1. 2008).

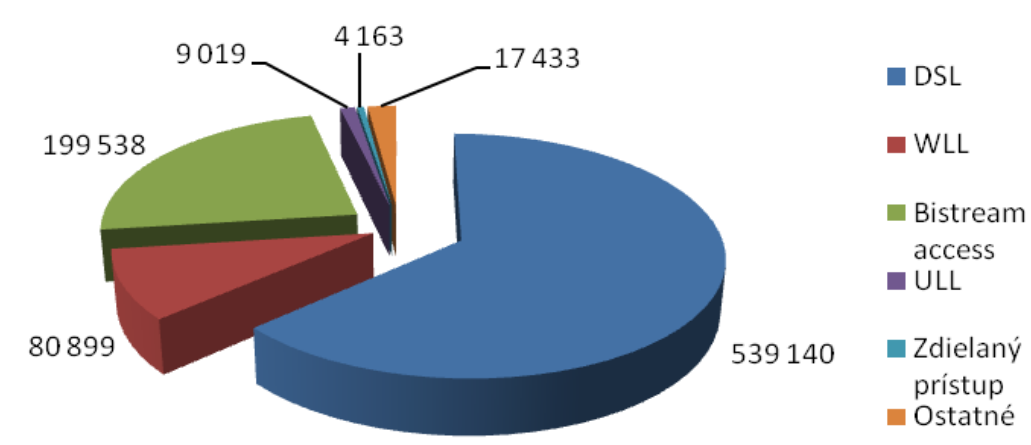

Obrázok 3. Analýza súčasného stavu pevných širokopásmových prístupových technológií v Mad’arsku Dostupné na: <http://ec.europa.eu/information_society/doc/factsheets/13thimplementation/9-12-hu.pdf> 


\section{Porovnanie jednotlivých krajín V4}

$\mathrm{Na}$ Slovensku v súčasnosti prevláda technológia DSL, obdobne ako aj v Mad'arsku a v Pol'sku, zatial' čo v Českej republike je táto technológia až na druhom mieste. Tabul'ka porovnáva počet xDSL prípojok krajinách V4 (stav k 1. 1. 2008).

\begin{tabular}{|l|l|l|}
\hline Krajina & xDSL prípojky & Tel. prípojky \\
\hline Česká republika & 562000 & 2992000 \\
\hline Mad'arsko & 695656 & 3666400 \\
\hline Pol'sko & 2158169 & 11400000 \\
\hline Slovensko & 220000 & 1415514 \\
\hline
\end{tabular}

Tabul'ka. Stav xDSL prípojok v niektorých štátoch EÚ

Dostupné na: <http://www.Int ernetprovsechny.cz/ceny-adsl-svet.php>

Z tabul'ky vyplýva, že je aj v porovnaní so susednými krajinami, ktoré sú tiež členmi EÚ, je Slovensko na poslednom mieste.

Zaujímavé porovnanie je pre technológie FTTH, kde je Slovensko na prvom mieste. $\mathrm{Na}$ druhom mieste sa nachádza Mad'arsko, za ním Česká republika a na poslednom mieste s najnižším počtom Pol'sko, kde je táto technológia oproti ostatným zanedbatel'ná. FTTH siet' Fibernet, ktorú buduje telekomunikačný operátor Orange, je najväčšou svojho druhu v našom regióne a mnoho i českých firiem tu získava skúsenosti pre chystané FTTx siete v Českej republike. Vzhl'adom ku svojej podstate sa na Slovenku jedná o prelomový projekt, ktorý okamžite po $100 \%$ sprevádzkovaní katapultuje Slovensko na internetovú špičku v Európe. Telekomunikačný operátor Orange sa tak stáva plnohodnotným telekomunikačným operátorom ponúkajúcim mobilné hlasové služby, rýchly internet cez optickú siet' do 200 tisíc domácností na Slovensku, pevné telefónne služby, IPTV a d'alšie ktoré na slovenskom trhu zatial' nikto komplexne neponúka.

Širokopásmový prístup pomocou káblového modemu je najviac používaný v Pol’sku, potom v Čechách a na koniec na Slovensku, pričom v Mad’arsku patrí medzi málo využívané technológie.

Technológia WLL je na Slovensku aj v Mad’arsku významná, ale najviac používanou je práve v Českej republike, kde prevláda aj nad DSL. V Pol'sku je jej podiel malý.

Slovenskí operátori sa vonuke rýchlych dátových sietí doslova predbiehajú. Slovenský trh sa vyvíja rýchlejšie v oblasti mobilného broadbandu, a v tejto oblasti panuje aj väčšia konkurencia a to aj vd'aka nižšej penetracii ADSL internetu.

Technológia HSDPA je na Slovensku hned' dvakrát: Orange Slovensko a T-Mobile, zatial' čo v Čechách je to len Telefónica O2, ktorá touto technológiou pokrýva ovel'a menšie územie ako na Slovensku. T-Mobile v Čechách používa UMTS dátovú siet', u nás na Slovensku T-Mobile začal budovat' dátovú siet' Flash- OFDM, známu pod názvom Flarion.

CATV je v Čechách dostupná zatial' len v niektorých častiach väčších miest ako sú Praha, Brno, Plzeň, Ostrava, Olomouc, Kralupy, Pardubice, Hradec Králové, atd', najväčšími 
operátormi sú UPC a Karneval. Je to jeden z najlepších spôsobov ako sa v C̆R pripojit' k internetu. Rýchlost' až $6 \mathrm{Mbit} / \mathrm{s}$ a technológiu CATV využíva až 60 tisíc obyvatel'ov.

WiFi využíva v Čechách v súčasnosti 424066 užívatel’ov prostredníctvom 868 poskytovatel'ov, zatial' čo na Slovensku je to len 47121 užívatel'ov a 197 poskytovatel'ov.

\section{Záver}

Širokopásmový prístup je dôležitým faktorom rozvoja znalostnej ekonomiky a spoločnosti, ale aj reálnou hrozbou zväčšovania rozdielov v spoločnosti. EÚ aj vláda SR stimulujú jeho rozvoj s dôrazom na podporu rovnomerného rozvoja všetkých štátov, regiónov a skupín obyvatel'stva.

Na Slovensku sú dostupné všetky technológie, vývoj penetrácie širokopásmového prístupu je razantný, ale úroveň aktuálnej penetrácie je aj z hl'adiska V4 nedostatočná. Väčší záujem o širokopásmový prístup závisí od životnej úrovne l'udí, ale aj od dostupnosti atraktívnych internetových služieb (e-verejná správa, e-zdravie, e-kultúra, e-banka, e-obchod a pod).

Ako vyplýva z výskumov Eurostatu, Slovensko má najpomalší internet z vyspelých krajín a zároveň najviac počítačov, ktoré nemajú pripojenie na internet.

\section{Literatúra}

[1] Žilinská univerzita v Žiline., Širokopásmový prístup v SR. 2006. Žilinská univerzita. Žilina, 2006. Dostupné na: <http://www.telecom.gov.sk/index/open_file.php?file=telekom/vyskum/pristup.pdf>

[2] PALOVSKÝ,T. 2008. Správa o stave slovenského internetu. Dostupné na: <http://www.pcspace.sk/content/v iew/1165/32/>

[3] Stratégia informatizácie spoločnosti v podmienkach SR a Akčný plán. Dostupné na: <http://www.elet.sk/brt/ egovernment/ vlastnymat.rtf>

[4] Národná stratégia pre širokopásmový prístup. 2005. Dostupné na:

< http://www.telecom.gov.sk/index/index.php?ids=3891>

\section{Grantová podpora}

Článok je súčast’ou riešenia úlohy Zvýšenie atraktívnosti vysokej školy prostredníctvom marketingovej komunikácie vzdelávacej inštitúcie - KEGA 3/5030/07. 